\title{
Recent Progress in Oculopharyngeal Muscular Dystrophy
}

\author{
Satoshi Yamashita
}

check for

updates

Citation: Yamashita, S. Recent Progress in Oculopharyngeal Muscular Dystrophy. J. Clin. Med. 2021, 10, 1375. https://doi.org/ $10.3390 /$ jcm 10071375

Academic Editor: Giuseppe Lanza

Received: 24 February 2021

Accepted: 26 March 2021

Published: 29 March 2021

Publisher's Note: MDPI stays neutral with regard to jurisdictional claims in published maps and institutional affiliations.

Copyright: (C) 2021 by the author. Licensee MDPI, Basel, Switzerland. This article is an open access article distributed under the terms and conditions of the Creative Commons Attribution (CC BY) license (https:/ / creativecommons.org/licenses/by/ $4.0 /)$.
Department of Neurology, Graduate School of Medical Sciences, Kumamoto University, Kumamoto 860-8556, Japan; y-stsh@kumamoto-u.ac.jp; Tel.: +81-96-373-5893

\begin{abstract}
Oculopharyngeal muscular dystrophy (OPMD) is a late-onset intractable myopathy, characterized by slowly progressive ptosis, dysphagia, and proximal limb weakness. It is caused by the abnormal expansion of the alanine-encoding (GCN)n trinucleotide repeat in the exon 1 of the polyadenosine (poly[A]) binding protein nuclear 1 gene (11-18 repeats in OPMD instead of the normal 10 repeats). As the disease progresses, the patients gradually develop a feeling of suffocation, regurgitation of food, and aspiration pneumonia, although the initial symptoms and the progression patterns vary among the patients. Autologous myoblast transplantation may provide therapeutic benefits by reducing swallowing problems in these patients. Therefore, it is important to assemble information on such patients for the introduction of effective treatments in nonendemic areas. Herein, we present a concise review of recent progress in clinical and pathological studies of OPMD and introduce an idea for setting up a nation-wide OPMD disease registry in Japan. Since it is important to understand patients' unmet medical needs, realize therapeutically targetable symptoms, and identify indices of therapeutic efficacy, our attempt to establish a unique patient registry of OPMD will be a helpful tool to address these urgent issues.
\end{abstract}

Keywords: oculopharyngeal muscular dystrophy; clinical characteristics; pathogenesis; therapeutic approach; patient registry

\section{Introduction}

Oculopharyngeal muscular dystrophy (OPMD), a late-onset myopathy, is characterized by slowly progressive ptosis, dysphagia, and proximal limb weakness. The disease is caused by the abnormal expansion of (GCN)n repeats (11-18 repeats in the disease condition vs 10 repeats in normal condition) in exon 1 of the poly (A) binding protein, nuclear 1 (PABPN1) gene [1]. OPMD is a rare form of muscular dystrophy, whose prevalence remains unknown in the non-endemic areas including Japan. According to the details available on the website ClinicalTrials.gov [2], 12 clinical studies on OPMD are ongoing at the moment. The outcome of a few of these studies may provide therapeutic benefits in alleviating the swallowing problems in these patients. Thus, there is an urgent need to assemble information regarding OPMD patients for the introduction of such effective treatment strategies. In this article, we present recent advances in OPMD research and introduce an idea for the setup of a nation-wide OPMD disease registry in Japan.

\section{Epidemiology}

OPMD is distributed worldwide, however, the prevalence of the disease varies in different ethnicities. The highest prevalence has been reported in the Bukhara Jews in Israel (1:600) [3], French-Canadians (1:1000) [4], and Hispanic in New Mexico [5], whereas the prevalence is 1:100,000-1,000,000 in the European population [6,7]. So far, case reports of a relatively small number of patients have been published from Italy [8], France [9], Germany [10], Uruguay [11], England [12], the Netherlands [13], Scotland [14], Spain [15], Denmark [16], Bulgaria [17], mainland China [18,19], Taiwan [20], Hong Kong [21], South Korea [22], Thailand [23], Malaysia [24], Singapore [25], Japan [26-28], and others. However, the precise epidemiological and clinicopathological characteristics of OPMD have not 
yet been investigated in Japan. In our single-institution experience, only six patients with OPMD were diagnosed during the last decade for which 414 patients underwent muscle biopsy.

\section{Presentation}

Major symptoms of OPMD are ptosis, swallowing dysfunction, and proximal limb weakness, although the frequency of appearance of these symptoms varies in different ethnicities. Previous reports revealed that almost all OPMD patients showed ptosis, whereas $62-100 \%$ and $20-81 \%$ of the patients showed swallowing dysfunction and proximal limb weakness, respectively [13]. The initial symptom is ptosis in approximately two-thirds of the OPMD patients, accompanied by ocular motor abnormalities in half of the patients [12]. Subsequent symptoms include lower proximal limb weakness followed by dysphagia. Since some patients develop lower proximal limb weakness alone [13], it may lead to a misdiagnosis of limb-girdle muscular dystrophy or myositis. A recent study revealed the possibility that the length of $(\mathrm{GCN}) n$ repeats defines the disease severity and progression [29]; patients with the longer $(\mathrm{GCN}) n$ repeats were diagnosed at an early age.

Patients with OPMD can manifest extramuscular symptoms (Figure 1), such as deterioration of respiratory function, including decreased forced expiratory volume in $1 \mathrm{~s} \mathrm{[30],}$ although cardiac functions may be preserved. Coexistence with dementia [31,32], executive function deficits [33], or peripheral neuropathy [34] was reported. Approximately half of the patients complained of fatigue and pain, and most of the patients were impaired in daily life activities, social participation, and ambulation [35].

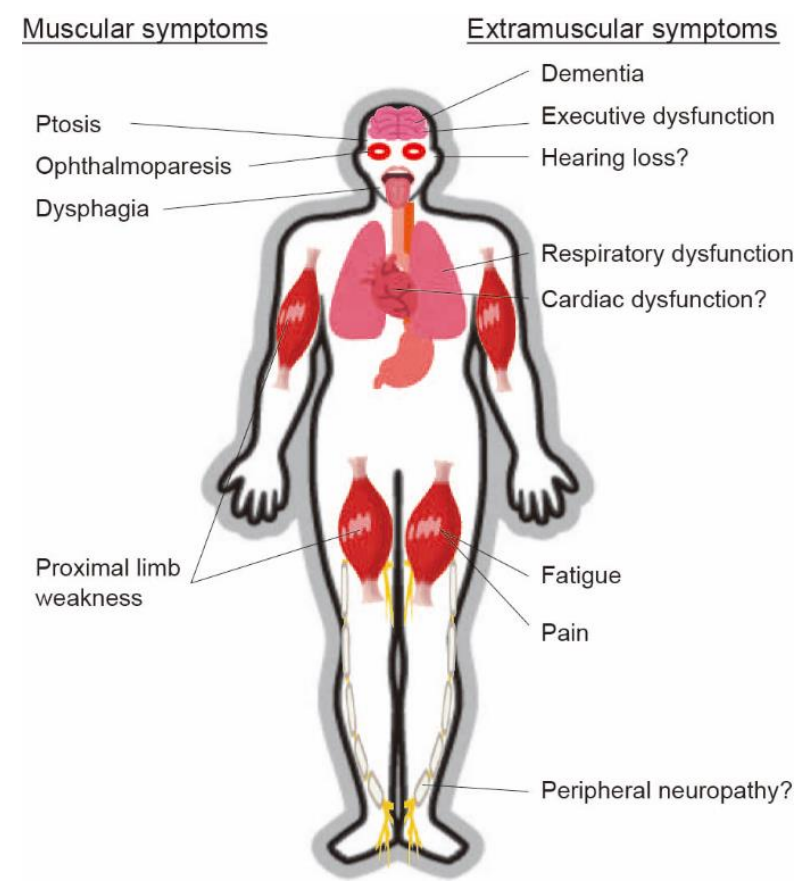

Figure 1. Various muscular and extramuscular symptoms of oculopharyngeal muscular dystrophy (OPMD). Patients with OPMD can manifest various muscular and extramuscular symptoms.

The autosomal recessive form of OPMD, which is caused by the homozygous expansion of (GCN)11 repeats in the PABPN1 gene, has been reported as late-onset and less severe than the dominant form [1], although it can manifest various symptoms with an unusual onset and atypical clinical course [36]. 


\section{Diagnosis}

\subsection{Blood Examination}

Serum levels of creatine kinase (CK) are slightly elevated in mild cases, but the levels are highly increased in more severe cases [29]. However, the levels of myogenic enzymes gradually decrease and are normalized as the disease advances (unpublished personal data), suggesting the limitation of using the enzymes as biomarkers for evaluating disease progression and therapeutic efficacy.

\subsection{Electrophysiology}

Needle electromyography demonstrated low-amplitude and short-duration motor unit potentials in the affected muscles in almost all the cases, although the electromyographic changes are non-specific for the disease [37]. Some case series reported the coexistence of peripheral neuropathy; other reports showed a low proportion of cases with a low amplitude of sensory nerve action potential on the sural nerves, while most of the cases had no abnormalities $[37,38]$.

\subsection{Histology}

The muscle histological features are characterized by varied fiber size, small rounded or angular fibers, and rimmed vacuoles (RV) in small fibers, although the frequency of fibers with RVs is only $0.6 \%$ and not necessarily all the patients show these changes [39]. Necrotic and regenerative myofibers are rarely observed. Mitochondrial abnormality has been reported, as evidenced by COX-negative fibers and ragged-red fibers [40-42]. A more specific finding is intranuclear tubulofilamentous aggregates of $8.5 \mathrm{~nm}$ outer diameter, which were observed approximately in $4 \%$ of the myonuclei by electron microscopy [39]. Of note, the detection of PABPN1-positive insoluble intranuclear aggregates was reportedly $100 \%$ sensitive and $96 \%$ specific for OPMD diagnosis [43].

\subsection{Radiology}

Recent evidence regarding radiological findings of OPMD has been accumulating. In previous studies with a relatively small number of patients, radiological features in magnetic resonance imaging (MRI) of OPMD patients included fatty replacement prominent in the adductor of the thigh, hamstring, soleus, gastrocnemius muscles, and muscles regulating the swallowing process including the tongue muscles [44,45]. A recent imaging study on 168 patients identified fatty replacement in $96.7 \%$ of all symptomatic patients, particularly in the most commonly affected muscles, including the tongue, adductor magnus, and soleus muscles [46]. In the same study, muscle pathology on MRI reportedly correlated with disease duration and functional impairment. Another study observed a highly negative correlation between clinical scores and visual imaging scores [44].

\subsection{Swallowing Examination}

Several studies have been conducted to figure out the mechanisms of dysphagia in OPMD. A manometric study showed abnormalities with simultaneous contractions and incomplete lower esophageal relaxation, as well as impaired upper esophageal sphincter/pharyngeal pressure [47]. A preliminary videofluorographic study revealed reduced pharyngeal constriction, incomplete laryngeal vestibule closure, and decreased speed and range of hyoid movement [48]. A more recent study showed that the proportions of the patients with pharyngeal dysphagia, cricopharyngeal bar, vallecular residue, and piriform sinus residue were $96 \%, 45 \%, 77.3 \%$, and $90.1 \%$, respectively [49]. In our investigation, the fiber-optic endoscopic evaluation identified a significant impairment in pharyngeal clearance resulting in salivary pooling (data submitted). Our videofluorographic evaluation showed severe disturbances in tongue base retraction and pharyngeal constriction and clearance. 


\subsection{Genetic Examination}

The underlying cause of OPMD is the abnormal expansion of (GCN)n repeats (11-18 repeats in the disease condition, while 10 repeats in normal condition) in the PABPN1 gene, located on the chromosome 14 [1]. One of the parents may have the mutation in the autosomal dominant form or both parents may have the (GCN)11 repeats expansion in the autosomal recessive form.

\subsection{Diagnosis}

OPMD diagnosis is based on typical clinical symptoms and molecular genetic testing. Patients with slowly progressive ptosis and dysphagia symptoms at onset after the age of 40 years, and positive family history, should be considered applicable for DNA sequencing, which is a gold standard for OPMD diagnosis [50]. Histological and electromyographic studies can be performed to exclude the possibility of other neuromuscular disorders.

\section{Pathogenesis and Therapeutic Approach}

Wild-type PABPN1 protein shuttles between the nuclei and the cytosol and play important roles in polyadenylation through enhancing the processivity of the poly(A) polymerase, modulating alternative polyadenylation sites, aiding nuclear RNA export, and regulating the steady-state level of long non-coding RNAs [51].

In patients with OPMD, the PABPN1 protein has an extra 11-18 alanine residues in the N-terminus due to the expanded (GCN)n repeats in the exon 1 of the PABPN1 gene. The following underlying mechanisms of OPMD have been speculated: (1) the mutated protein forms intranuclear aggregates, leading to toxicity; (2) the intranuclear aggregates sequester various transcription factors, molecular chaperones, RNA binding proteins, and RNAs necessary for cell maintenance; (3) reduction in the levels of wild-type PABPN1 by half suppresses its native function; or (4) the abnormal PABPN1 protein suppresses the function of wild-type protein [51]. Recent progress in therapeutic strategies for the treatment of OPMD is described below (Figure 2).

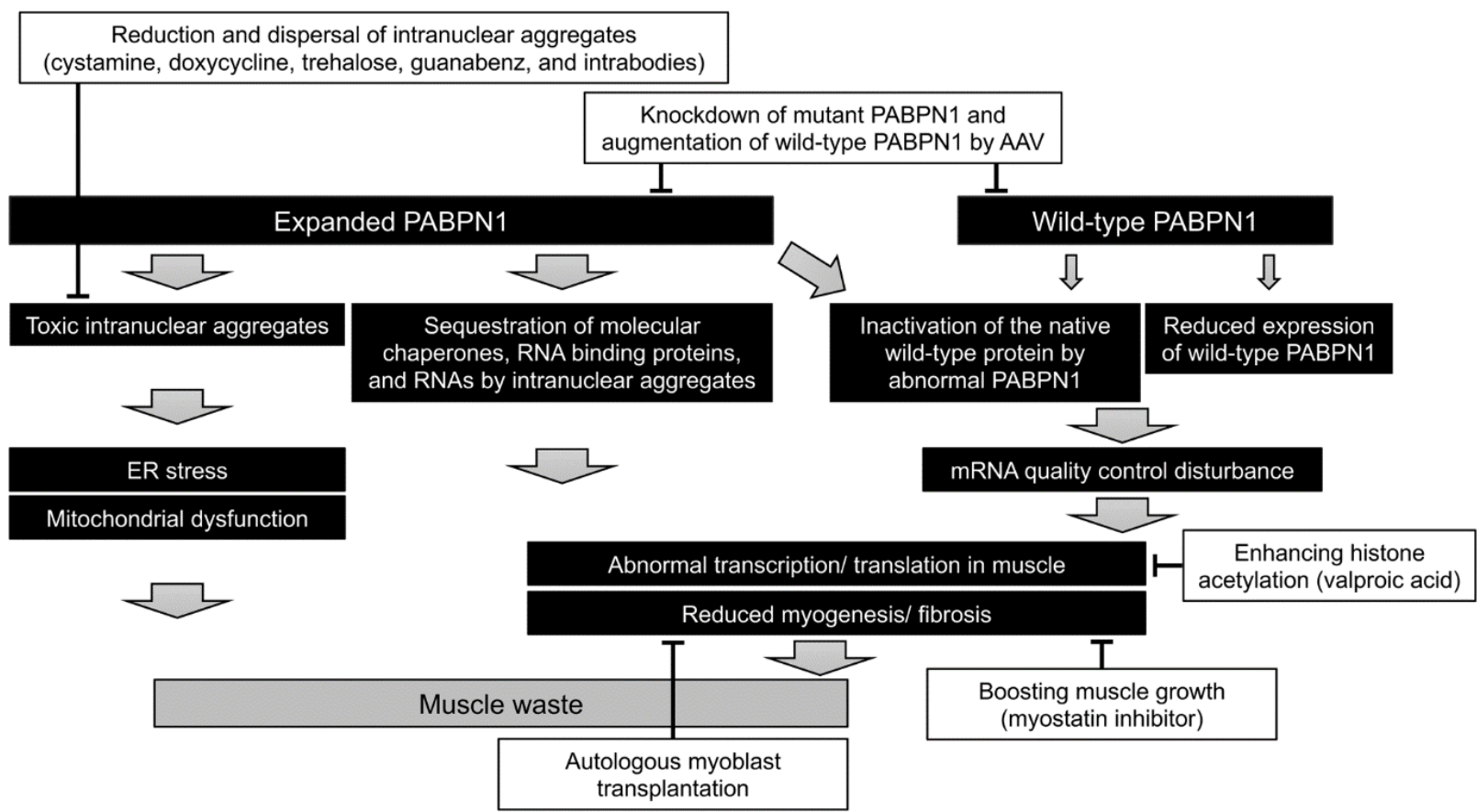

Figure 2. Pathogenesis and therapeutic approach for OPMD. Several therapeutic strategies have been proposed based on the pathogenesis of OPMD, such as (1) knockdown of mutant PABPN1 and/or augmentation of wild-type PABPN1 using adeno-associated virus (AAV) vectors; (2) boosting muscle growth using myostatin inhibitor; (3) reduction and dispersal of intranuclear aggregates using cystamine, doxycycline, trehalose, guanabenz, and intrabodies; and (4) autologous myoblast transplantation combined with cricopharyngeal myotomy. 


\subsection{Knockdown of Mutant PABPN1 and/or Augmentation of Wild-Type PABPN1}

In a mice model of OPMD, co-delivery of two adeno-associated virus (AAV) vectors, the first expressing three shRNAs under the control of RNA polymerase III promoter and the second expressing wild-type human PABPN1 under the control of a skeletal and cardiac muscle-specific promoter significantly improved the histopathological features [52]. Using a dual AAV vector expressing both the cassettes also produced similar effects, suggesting a possible clinical application of gene therapy [53].

\subsection{Boosting of Muscle Growth}

Systemic delivery of a monoclonal antibody that inhibits myostatin in a mouse model of OPMD improved the body and muscle mass, increased the muscle strength and the myofiber diameter, and reduced the expression of fibrosis markers, although no effect on intranuclear inclusions was observed [54]. However, a more recent study showed that inhibition of myostatin failed to revert the muscle atrophy in OPMD mouse model but effectively reduced the expression of histological markers of fibrosis in the treated muscles [55]. Based on these studies, it could be concluded that inhibition of myostatin commonly prevents muscle fibrosis.

\subsection{Reduction and Dispersal of Intranuclear Aggregates}

Since the intranuclear aggregates of the mutant PABPN1 protein might be toxic, pharmacological approaches to specifically target these aggregates using cystamine [56], doxycycline [57], trehalose [58], guanabenz [59], and intrabodies [60] successfully ameliorated the disease in several models of OPMD. The soluble form of the mutant PABPN1 might also produce toxicity [61] by interacting with the components of the transcription complex/histone acetylation [62]. Valproic acid, a direct inhibitor of histone deacetylase classes I and II, could ameliorate the mutant PABPN1 toxicity in cellular and worm models of OPMD by enhancing the level of histone acetylation [63]. Further studies are required to understand the disease pathogenesis involving the soluble form of mutant PABPN1.

\subsection{Autologous Myoblast Transplantation}

A previous study showed that myoblasts isolated from the unaffected muscles of OPMD patients proliferated and differentiated normally, whereas myoblasts isolated from the affected muscles (cricopharyngeal muscle) exhibited reduced myogenicity [64]. A phase I/IIa clinical study based on the grafting of autologous myoblasts isolated from unaffected muscles (quadriceps or sternocleidomastoid) into the pharyngeal muscles following a cricopharyngeal myotomy showed short and long-term safety, tolerability, an improvement in the quality of life score, and no functional degradation in swallowing [65]. As of now, autologous myoblast transplantation stands on the verge of clinical application.

\subsection{Mitochondrial Restoration}

Mitochondrial abnormality has been proposed as the possible etiology, although the molecular pathogenesis remains unclear. A recent knock-in mouse model containing an alanine-expanded PABPN1 allele under the control of the native PABPN1 promoter and a wild-type PABPN1 allele showed that expression of proteins involved in the mitochondrial metabolism was significantly reduced in the transgenic mice compared to the wild-type mice, along with a significant reduction in the expression of SDHB (Complex II), COX1 (Complex IV), and ATP5A (Complex V) proteins in the affected muscles [66]. Our previous study revealed the abnormal accumulation of the expanded PABPN1 protein in the mitochondria is possibly associated with the mitochondrial abnormality in OPMD [67]. Thus, therapeutic approaches targeting the restoration of the mitochondrial functions should be considered. 


\section{Current Treatment and Prognosis}

OPMD patients gradually develop a feeling of suffocation, regurgitation of food, and aspiration pneumonia as the disease progresses, although the rate of progression is different between the patients [68]. Repetitive aspiration may lead to death associated with malnutrition. OPMD reportedly has a little effect on the life expectancy because repeated aspiration occurs only at the more advanced stage. However, such conditions disturb the quality of life in patients $[69,70]$. A small proportion of the OPMD patients progressively get bound to wheelchairs, therefore, the clinicians should set up medical care services tailored to each patient.

Until now, no effective treatments have been developed for the disease. To control dysphagia, injecting botulin toxin into the cricopharyngeal muscle reportedly improved the swallowing function in $59 \%$ of the patients whereas $24 \%$ and $14 \%$ of the patients showed adverse dysphonia and deterioration of swallowing function, respectively [71]. Autologous myoblast transplantation accompanied by cricopharyngeal myotomy has been reported to enhance the quality of life in patients and preserve the swallowing function [65]. Moreover, since there are various mechanisms of dysphagia, a wide range of preventive approaches for aspiration should be employed. For ptosis, patients with a fair to good levator function usually undergo a levator-based procedure including levator advancement or resection, whereas those with a poor levator function undergo a frontalis suspension. However, the recurrence rate of ptosis in patients followed for at least 9 years has been reported to be $13 \%$ [72]. Thus, better approaches should be considered for long-term maintenance.

\section{Patient Registry}

Patient registry is an organized system that uses observational study methods to collect uniform data (clinical and other) to evaluate specified outcomes for a population defined by a particular disease, condition, or exposure, and that serves a predetermined scientific, clinical, or policy purpose(s) [73]. A flood of clinical trials is being planned and conducted for muscular dystrophies, including Duchenne and Becker muscular dystrophies. However, there are many challenges for clinical trials of such rare diseases, including OPMD. These include limited epidemiological data, the total number of patients, the natural history of the disease, assembling a certain number of patients, and adequate clinical outcome measures [74]. As solutions to these problems, patient registries are a helpful resource, particularly in cases of rare diseases.

Recently, the OPMD patient registry has been created at the University of New Mexico Health Sciences Center based on the rare disease registry standard created by the NIH Office of Rare Diseases Research [75]. It aims to understand how OPMD affects people's lives; recruit participants for future studies on the disease; and establish communication among researchers, patients, and families (according to the website of the University of New Mexico). The achievements include an understanding of the relationship between physical and dysphagia symptoms and quality of life [69,70].

In Japan, the OPMD patient registry has not been established yet, although a national registry of Japanese DMD/BMD patients (REgistry of MUscular DYstrophy; Remudy. http:/ / www.remudy.jp/ (accessed on 24 February 2021)) in collaboration with TREATNMD has been developed since 2009 [74]. By sharing the system environments, we are going to develop the unique patient registry of OPMD, which would enable us to collect epidemiological data, including the number of patients and the natural history of the disease. Registered fields will include the presence or absence of family history, consanguinity, muscle histology (rimmed vacuoles, intranuclear aggregates), (GCN)n repeat-length, height, weight, age at onset, initial symptoms, age at ptosis, diplopia, dysarthria, dysphagia, diet restrictions/alterations, tube feeding, lower proximal weakness, gait disorder, upper proximal weakness, any other complications including neuropathy, an examination of the respiratory (\% vital capacity (VC) and \% forced vital capacity $(\mathrm{FVC})$ ) and cardiac functions (\% ejection fraction $[\mathrm{EF}]$ and \% fractional shortening (FS)), electrocardiography, and serum CK levels (Table 1). 
Table 1. Registered fields for the proposed nation-wide OPMD patient registry in Japan.

\begin{tabular}{|c|c|}
\hline Basic Items & Name \\
\hline & $\begin{array}{c}\text { Date of birth } \\
\text { Nationality } \\
\text { Address } \\
\text { Participation in patients' association } \\
\text { Proposal for clinical trials }\end{array}$ \\
\hline Clinical items & $\begin{array}{l}\text { Presence or absence of family history } \\
\text { Consanguinity } \\
\text { Muscle histology (rimmed vacuoles, intranuclear aggregates) } \\
\text { (GCN)n repeat-length } \\
\text { Height and weight } \\
\text { Age at onset } \\
\text { Initial symptoms } \\
\text { Age at ptosis } \\
\text { Age at diplopia } \\
\text { Age at dysarthria } \\
\text { Age at dysphagia } \\
\text { Age at tube feeding } \\
\text { Age at diet restrictions/alterations } \\
\text { Age at lower proximal weakness } \\
\text { Age at gait disorder } \\
\text { Age at upper proximal weakness } \\
\text { Any other complications including neuropathy } \\
\text { Respiratory (\% vital capacity and \% forced vital capacity) } \\
\text { Cardiac functions (\% ejection fraction and \% fractional shortening) } \\
\text { Electrocardiography } \\
\text { Serum CK levels }\end{array}$ \\
\hline
\end{tabular}

\section{Conclusions}

OPMD was first discovered in five French-Canadian patients in the second consecutive generation by Taylor in 1915. Since the identification of the causative gene in 1998, the research on the pathophysiology has progressed rapidly. However, clinicoepidemiological studies have not been performed in various parts of the world except endemic areas, including the Province of Quebec; Israel; and New Mexico. Based on the achievements of basic research, emergence of novel therapeutic approaches for OPMD is expected in the near future. Thus, it has become increasingly important to know patients' unmet medical needs, realize therapeutically targetable symptoms, and identify indices of therapeutic efficacy. Our attempt to establish a unique patient registry of OPMD would be a helpful tool to address these urgent issues.

Funding: This research was funded by an Intramural Research Grant (29-3, 2-4) for Neurological and Psychiatric Disorders of National Center of Neurology and Psychiatry, Japan.

Institutional Review Board Statement: Not applicable.

Informed Consent Statement: Not applicable.

Data Availability Statement: Not applicable.

Acknowledgments: We acknowledge all of the staff members of Department of Neurology, Graduate School of Medical Sciences, Kumamoto University for their support in writing this review, providing materials, and editing.

Conflicts of Interest: The authors declare no conflict of interest. The funders had no role in the design of the study; in the collection, analyses, or interpretation of data; in the writing of the manuscript; or in the decision to publish the results. 


\section{References}

1. Brais, B.; Bouchard, J.P.; Xie, Y.G.; Rochefort, D.L.; Chretien, N.; Tome, F.M.; Lafreniere, R.G.; Rommens, J.M.; Uyama, E.; Nohira, O.; et al. Short GCG expansions in the PABP2 gene cause oculopharyngeal muscular dystrophy. Nat. Genet. 1998, 18, 164-167. [CrossRef]

2. ClinicalTrials.gov. Available online: https://clinicaltrials.gov/ct2/results?cond=Oculopharyngeal+Muscular+Dystrophy\&term $=$ \&cntry $=\&$ state $=\&$ city $=\&$ dist $=($ accessed on 23 February 2021).

3. Blumen, S.C.; Nisipeanu, P.; Sadeh, M.; Asherov, A.; Tome, F.M.; Korczyn, A.D. Clinical features of oculopharyngeal muscular dystrophy among Bukhara Jews. Neuromuscul. Disord. 1993, 3, 575-577. [CrossRef]

4. Bouchard, J.P. Andre Barbeau and the oculopharyngeal muscular dystrophy in French Canada and North America. Neuromuscul. Disord. 1997, 7 (Suppl. 1), S5-S11. [CrossRef]

5. $\quad$ Becher, M.W.; Morrison, L.; Davis, L.E.; Maki, W.C.; King, M.K.; Bicknell, J.M.; Reinert, B.L.; Bartolo, C.; Bear, D.G. Oculopharyngeal muscular dystrophy in Hispanic New Mexicans. JAMA 2001, 286, 2437-2440. [CrossRef] [PubMed]

6. Brais, B.; Rouleau, G.A.; Bouchard, J.P.; Fardeau, M.; Tome, F.M. Oculopharyngeal muscular dystrophy. Semin. Neurol. 1999, 19, 59-66. [CrossRef] [PubMed]

7. Deenen, J.C.; Horlings, C.G.; Verschuuren, J.J.; Verbeek, A.L.; van Engelen, B.G. The Epidemiology of Neuromuscular Disorders: A Comprehensive Overview of the Literature. J. Neuromuscul. Dis. 2015, 2, 73-85. [CrossRef] [PubMed]

8. Meola, G.; Sansone, V.; Rotondo, G.; Tome, F.M.; Bouchard, J.P. Oculopharyngeal muscular dystrophy in Italy. Neuromuscul. Disord. 1997, 7 (Suppl. 1), S53-S56. [CrossRef]

9. Perie, S.; Eymard, B.; Laccourreye, L.; Chaussade, S.; Fardeau, M.; Lacau St Guily, J. Dysphagia in oculopharyngeal muscular dystrophy: A series of 22 French cases. Neuromuscul. Disord. 1997, 7 (Suppl. 1), S96-S99. [CrossRef]

10. Porschke, H.; Kress, W.; Reichmann, H.; Goebel, H.H.; Grimm, T. Oculopharyngeal muscular dystrophy in a northern German family linked to chromosome 14q, and presenting carnitine deficiency. Neuromuscul. Disord. 1997, 7 (Suppl. 1), S57-S62. [CrossRef]

11. Medici, M.; Pizzarossa, C.; Skuk, D.; Yorio, D.; Emmanuelli, G.; Mesa, R. Oculopharyngeal muscular dystrophy in Uruguay. Neuromuscul. Disord. 1997, 7 (Suppl. 1), S50-S52. [CrossRef]

12. Hill, M.E.; Creed, G.A.; McMullan, T.F.; Tyers, A.G.; Hilton-Jones, D.; Robinson, D.O.; Hammans, S.R. Oculopharyngeal muscular dystrophy: Phenotypic and genotypic studies in a UK population. Brain 2001, 124, 522-526. [CrossRef]

13. Van Der Sluijs, B.M.; Hoefsloot, L.H.; Padberg, G.W.; Van Der Maarel, S.M.; Van Engelen, B.G. Oculopharyngeal muscular dystrophy with limb girdle weakness as major complaint. J. Neurol. 2003, 250, 1307-1312. [CrossRef]

14. Agarwal, P.K.; Mansfield, D.C.; Mechan, D.; Al-Shahi Salman, R.; Davenport, R.J.; Connor, M.; Metcalfe, R.; Petty, R. Delayed diagnosis of oculopharyngeal muscular dystrophy in Scotland. Br. J. Ophthalmol. 2012, 96, 281-283. [CrossRef] [PubMed]

15. Tondo, M.; Gamez, J.; Gutierrez-Rivas, E.; Medel-Jimenez, R.; Martorell, L. Genotype and phenotype study of 34 Spanish patients diagnosed with oculopharyngeal muscular dystrophy. J. Neurol. 2012, 259, 1546-1552. [CrossRef]

16. Mensah, A.; Witting, N.; Duno, M.; Milea, D.; Vissing, J. Delayed diagnosis of oculopharyngeal muscular dystrophy in Denmark: From initial ptosis to genetic testing. Acta Ophthalmol. 2014, 92, e247-e249. [CrossRef] [PubMed]

17. Blumen, S.C.; Kesler, A.; Dabby, R.; Shalev, S.; Khayat, M.; Almog, Y.; Zoldan, J.; Benninger, F.; Drory, V.E.; Gurevich, M.; et al. Oculopharyngeal muscular dystrophy among Bulgarian Jews: A new cluster? Isr. Med. Assoc. J. 2013, 15, 748-752. [PubMed]

18. Chien, Y.Y. Oculopharyngeal muscular dystrophy-An under-diagnosed disease in China? Report a China-born Chinese with PABPN1 mutation and epidemiology review of the literature. J. Formos. Med. Assoc. 2012, 111, 397-402. [CrossRef]

19. Shan, J.; Chen, B.; Lin, P.; Li, D.; Luo, Y.; Ji, K.; Zheng, J.; Yuan, Y.; Yan, C. Oculopharyngeal muscular dystrophy: Phenotypic and genotypic studies in a Chinese population. Neuromolecular. Med. 2014, 16, 782-786. [CrossRef]

20. Huang, C.L.; Wu, S.L.; Lai, S.C.; Lu, C.S.; Wu-Chou, Y.H. Oculopharyngeal muscular dystrophy-A genetically verified taiwanese family. Chang Gung Med. J. 2010, 33, 44-50.

21. Luk, H.M.; Lo, I.F.; Fu, K.H.; Lui, C.H.; Tong, T.M.; Chan, D.H.; Lam, S.T. Oculopharyngeal muscular dystrophy: Underdiagnosed disease in Hong Kong. Hong Kong Med. J. 2013, 19, 556-559. [CrossRef] [PubMed]

22. Bae, J.S.; Ki, C.S.; Kim, J.W.; Kim, B.J. Identification of a novel mutation in a Korean patient with oculopharyngeal muscular dystrophy. J. Clin. Neurosci. 2007, 14, 89-92. [CrossRef] [PubMed]

23. Pulkes, T.; Papsing, C.; Busabaratana, M.; Dejthevaporn, C.; Witoonpanich, R. Mutation and haplotype analysis of oculopharyngeal muscular dystrophy in Thai patients. J. Clin. Neurosci. 2011, 18, 674-677. [CrossRef] [PubMed]

24. Goh, K.J.; Wong, K.T.; Nishino, I.; Minami, N.; Nonaka, I. Oculopharyngeal muscular dystrophy with PABPN1 mutation in a Chinese Malaysian woman. Neuromuscul. Disord. 2005, 15, 262-264. [CrossRef] [PubMed]

25. Saini, M.; Tan, N.C.; Chai, J. Oculopharyngeal Muscular Dystrophy in Singapore: Not So Rare. Ann. Acad. Med. Singap. 2018, 47, 349-352. [PubMed]

26. Uyama, E.; Nohira, O.; Chateau, D.; Tokunaga, M.; Uchino, M.; Okabe, T.; Ando, M.; Tome, F.M. Oculopharyngeal muscular dystrophy in two unrelated Japanese families. Neurology 1996, 46, 773-778. [CrossRef] [PubMed]

27. Uyama, E.; Nohira, O.; Tome, F.M.; Chateau, D.; Tokunaga, M.; Ando, M.; Maki, M.; Okabe, T.; Uchino, M. Oculopharyngeal muscular dystrophy in Japan. Neuromuscul. Disord. 1997, 7 (Suppl. 1), S41-S49. [CrossRef]

28. Nagashima, T.; Kato, H.; Kase, M.; Maguchi, S.; Mizutani, Y.; Matsuda, K.; Chuma, T.; Mano, Y.; Goto, Y.; Minami, N.; et al. Oculopharyngeal muscular dystrophy in a Japanese family with a short GCG expansion (GCG)(11) in PABP2 gene. Neuromuscul. Disord. 2000, 10, 173-177. [CrossRef] 
29. Richard, P.; Trollet, C.; Stojkovic, T.; de Becdelievre, A.; Perie, S.; Pouget, J.; Eymard, B. Neurologists of French Neuromuscular Reference Centers. Correlation between PABPN1 genotype and disease severity in oculopharyngeal muscular dystrophy. Neurology 2017, 88, 359-365. [CrossRef]

30. Witting, N.; Mensah, A.; Kober, L.; Bundgaard, H.; Petri, H.; Duno, M.; Milea, D.; Vissing, J. Ocular, bulbar, limb, and cardiopulmonary involvement in oculopharyngeal muscular dystrophy. Acta Neurol. Scand. 2014, 130, 125-130. [CrossRef] [PubMed]

31. Mizoi, Y.; Yamamoto, T.; Minami, N.; Ohkuma, A.; Nonaka, I.; Nishino, I.; Tamura, N.; Amano, T.; Araki, N. Oculopharyngeal muscular dystrophy associated with dementia. Intern. Med. 2011, 50, 2409-2412. [CrossRef]

32. Nisbet, M.K.; Marshall, L. Oculopharyngeal muscular dystrophy (OPMD) and dementia in a 75-year-old female. BMJ Case Rep. 2019, 12. [CrossRef]

33. Dubbioso, R.; Moretta, P.; Manganelli, F.; Fiorillo, C.; Iodice, R.; Trojano, L.; Santoro, L. Executive functions are impaired in heterozygote patients with oculopharyngeal muscular dystrophy. J. Neurol. 2012, 259, 833-837. [CrossRef] [PubMed]

34. Boukriche, Y.; Maisonobe, T.; Masson, C. Neurogenic involvement in a case of oculopharyngeal muscular dystrophy. Muscle Nerve 2001, 25, 98-101. [CrossRef]

35. Van der Sluijs, B.M.; Knoop, H.; Bleijenberg, G.; van Engelen, B.G.; Voermans, N.C. The Dutch patients' perspective on oculopharyngeal muscular dystrophy: A questionnaire study on fatigue, pain and impairments. Neuromuscul. Disord. 2016, 26, 221-226. [CrossRef] [PubMed]

36. Semmler, A.; Kress, W.; Vielhaber, S.; Schroder, R.; Kornblum, C. Variability of the recessive oculopharyngeal muscular dystrophy phenotype. Muscle Nerve 2007, 35, 681-684. [CrossRef] [PubMed]

37. Jones, L.K., Jr.; Harper, C.M. Clinical and electrophysiologic features of oculopharyngeal muscular dystrophy: Lack of evidence for an associated peripheral neuropathy. Clin. Neurophysiol. 2010, 121, 870-873. [CrossRef] [PubMed]

38. Luigetti, M.; Lo Monaco, M.; Mirabella, M.; Primiano, G.; Lucchini, M.; Monforte, M.; Servidei, S. Oculopharyngeal muscular dystrophy: Clinical and neurophysiological features. Clin. Neurophysiol. 2015, 126, 2406-2408. [CrossRef]

39. Tome, F.M.; Chateau, D.; Helbling-Leclerc, A.; Fardeau, M. Morphological changes in muscle fibers in oculopharyngeal muscular dystrophy. Neuromuscul. Disord. 1997, 7 (Suppl. 1), S63-S69. [CrossRef]

40. Pratt, M.F.; Meyers, P.K. Oculopharyngeal muscular dystrophy: Recent ultrastructural evidence for mitochondrial abnormalities. Laryngoscope 1986, 96, 368-373. [CrossRef]

41. Pauzner, R.; Blatt, I.; Mouallem, M.; Ben-David, E.; Farfel, Z.; Sadeh, M. Mitochondrial abnormalities in oculopharyngeal muscular dystrophy. Muscle Nerve 1991, 14, 947-952. [CrossRef] [PubMed]

42. Gambelli, S.; Malandrini, A.; Ginanneschi, F.; Berti, G.; Cardaioli, E.; De Stefano, R.; Franci, M.; Salvadori, C.; Mari, F.; Bruttini, M.; et al. Mitochondrial abnormalities in genetically assessed oculopharyngeal muscular dystrophy. Eur. Neurol. 2004, 51, 144-147. [CrossRef] [PubMed]

43. Galimberti, V.; Tironi, R.; Lerario, A.; Scali, M.; Del Bo, R.; Rodolico, C.; Brizzi, T.; Gibertini, S.; Maggi, L.; Mora, M.; et al. Value of insoluble PABPN1 accumulation in the diagnosis of oculopharyngeal muscular dystrophy. Eur. J. Neurol. 2019. [CrossRef] [PubMed]

44. Fischmann, A.; Gloor, M.; Fasler, S.; Haas, T.; Rodoni Wetzel, R.; Bieri, O.; Wetzel, S.; Heinimann, K.; Scheffler, K.; Fischer, D. Muscular involvement assessed by MRI correlates to motor function measurement values in oculopharyngeal muscular dystrophy. J. Neurol. 2011, 258, 1333-1340. [CrossRef]

45. King, M.K.; Lee, R.R.; Davis, L.E. Magnetic resonance imaging and computed tomography of skeletal muscles in oculopharyngeal muscular dystrophy. J. Clin. Neuromuscul. Dis. 2005, 6, 103-108. [CrossRef]

46. Alonso-Jimenez, A.; Kroon, R.; Alejaldre-Monforte, A.; Nunez-Peralta, C.; Horlings, C.G.C.; van Engelen, B.G.M.; Olive, M.; Gonzalez, L.; Verges-Gil, E.; Paradas, C.; et al. Muscle MRI in a large cohort of patients with oculopharyngeal muscular dystrophy. J. Neurol. Neurosurg. Psychiatry 2019, 90, 576-585. [CrossRef]

47. Castell, J.A.; Castell, D.O.; Duranceau, C.A.; Topart, P. Manometric characteristics of the pharynx, upper esophageal sphincter, esophagus, and lower esophageal sphincter in patients with oculopharyngeal muscular dystrophy. Dysphagia 1995, 10, 22-26. [CrossRef]

48. Waito, A.A.; Steele, C.M.; Peladeau-Pigeon, M.; Genge, A.; Argov, Z. A Preliminary Videofluoroscopic Investigation of Swallowing Physiology and Function in Individuals with Oculopharyngeal Muscular Dystrophy (OPMD). Dysphagia 2018, 33, 789-802. [CrossRef]

49. Tabor, L.C.; Plowman, E.K.; Romero-Clark, C.; Youssof, S. Oropharyngeal dysphagia profiles in individuals with oculopharyngeal muscular dystrophy. Neurogastroenterol. Motil. 2018, 30, e13251. [CrossRef] [PubMed]

50. Abu-Baker, A.; Rouleau, G.A. Oculopharyngeal muscular dystrophy: Recent advances in the understanding of the molecular pathogenic mechanisms and treatment strategies. Biochim. Biophys. Acta 2007, 1772, 173-185. [CrossRef]

51. Banerjee, A.; Apponi, L.H.; Pavlath, G.K.; Corbett, A.H. PABPN1: Molecular function and muscle disease. FEBS J. 2013, 280, 4230-4250. [CrossRef]

52. Malerba, A.; Klein, P.; Bachtarzi, H.; Jarmin, S.A.; Cordova, G.; Ferry, A.; Strings, V.; Espinoza, M.P.; Mamchaoui, K.; Blumen, S.C.; et al. PABPN1 gene therapy for oculopharyngeal muscular dystrophy. Nat. Commun. 2017, 8, 14848. [CrossRef] 
53. Malerba, A.; Klein, P.; Lu-Nguyen, N.; Cappellari, O.; Strings-Ufombah, V.; Harbaran, S.; Roelvink, P.; Suhy, D.; Trollet, C.; Dickson, G. Established PABPN1 intranuclear inclusions in OPMD muscle can be efficiently reversed by AAV-mediated knockdown and replacement of mutant expanded PABPN1. Hum. Mol. Genet. 2019, 28, 3301-3308. [CrossRef] [PubMed]

54. Harish, P.; Malerba, A.; Lu-Nguyen, N.; Forrest, L.; Cappellari, O.; Roth, F.; Trollet, C.; Popplewell, L.; Dickson, G. Inhibition of myostatin improves muscle atrophy in oculopharyngeal muscular dystrophy (OPMD). J. Cachexia Sarcopenia Muscle 2019, 10, 1016-1026. [CrossRef]

55. Harish, P.; Forrest, L.; Herath, S.; Dickson, G.; Malerba, A.; Popplewell, L. Inhibition of Myostatin Reduces Collagen Deposition in a Mouse Model of Oculopharyngeal Muscular Dystrophy (OPMD) with Established Disease. Front. Physiol. 2020, 11, 184. [CrossRef]

56. Davies, J.E.; Rose, C.; Sarkar, S.; Rubinsztein, D.C. Cystamine suppresses polyalanine toxicity in a mouse model of oculopharyngeal muscular dystrophy. Sci. Transl. Med. 2010, 2, 34-40. [CrossRef]

57. Davies, J.E.; Wang, L.; Garcia-Oroz, L.; Cook, L.J.; Vacher, C.; O’Donovan, D.G.; Rubinsztein, D.C. Doxycycline attenuates and delays toxicity of the oculopharyngeal muscular dystrophy mutation in transgenic mice. Nat. Med. 2005, 11, 672-677. [CrossRef]

58. Davies, J.E.; Sarkar, S.; Rubinsztein, D.C. Trehalose reduces aggregate formation and delays pathology in a transgenic mouse model of oculopharyngeal muscular dystrophy. Hum. Mol. Genet. 2006, 15, 23-31. [CrossRef]

59. Malerba, A.; Roth, F.; Harish, P.; Dhiab, J.; Lu-Nguyen, N.; Cappellari, O.; Jarmin, S.; Mahoudeau, A.; Ythier, V.; Laine, J.; et al. Pharmacological modulation of the ER stress response ameliorates oculopharyngeal muscular dystrophy. Hum. Mol. Genet. 2019, 28, 1694-1708. [CrossRef]

60. Chartier, A.; Raz, V.; Sterrenburg, E.; Verrips, C.T.; van der Maarel, S.M.; Simonelig, M. Prevention of oculopharyngeal muscular dystrophy by muscular expression of Llama single-chain intrabodies in vivo. Hum. Mol. Genet. 2009, 18, 1849-1859. [CrossRef]

61. Messaed, C.; Dion, P.A.; Abu-Baker, A.; Rochefort, D.; Laganiere, J.; Brais, B.; Rouleau, G.A. Soluble expanded PABPN1 promotes cell death in oculopharyngeal muscular dystrophy. Neurobiol. Dis. 2007, 26, 546-557. [CrossRef]

62. Kim, Y.J.; Noguchi, S.; Hayashi, Y.K.; Tsukahara, T.; Shimizu, T.; Arahata, K. The product of an oculopharyngeal muscular dystrophy gene, poly(A)-binding protein 2, interacts with SKIP and stimulates muscle-specific gene expression. Hum. Mol. Genet. 2001, 10, 1129-1139. [CrossRef]

63. Abu-Baker, A.; Parker, A.; Ramalingam, S.; Laganiere, J.; Brais, B.; Neri, C.; Dion, P.; Rouleau, G. Valproic acid is protective in cellular and worm models of oculopharyngeal muscular dystrophy. Neurology 2018, 91, e551-e561. [CrossRef] [PubMed]

64. Perie, S.; Mamchaoui, K.; Mouly, V.; Blot, S.; Bouazza, B.; Thornell, L.E.; St Guily, J.L.; Butler-Browne, G. Premature proliferative arrest of cricopharyngeal myoblasts in oculo-pharyngeal muscular dystrophy: Therapeutic perspectives of autologous myoblast transplantation. Neuromuscul. Disord. 2006, 16, 770-781. [CrossRef] [PubMed]

65. Perie, S.; Trollet, C.; Mouly, V.; Vanneaux, V.; Mamchaoui, K.; Bouazza, B.; Marolleau, J.P.; Laforet, P.; Chapon, F.; Eymard, B.; et al. Autologous myoblast transplantation for oculopharyngeal muscular dystrophy: A phase I/IIa clinical study. Mol. Ther. 2014, 22, 219-225. [CrossRef] [PubMed]

66. Vest, K.E.; Phillips, B.L.; Banerjee, A.; Apponi, L.H.; Dammer, E.B.; Xu, W.; Zheng, D.; Yu, J.; Tian, B.; Pavlath, G.K.; et al. Novel mouse models of oculopharyngeal muscular dystrophy (OPMD) reveal early onset mitochondrial defects and suggest loss of PABPN1 may contribute to pathology. Hum. Mol. Genet. 2017, 26, 3235-3252. [CrossRef] [PubMed]

67. Doki, T.; Yamashita, S.; Wei, F.Y.; Hara, K.; Yamamoto, T.; Zhang, Z.; Zhang, X.; Tawara, N.; Hino, H.; Uyama, E.; et al. Mitochondrial localization of PABPN1 in oculopharyngeal muscular dystrophy. Lab. Invest. 2019, 99, 1728-1740. [CrossRef]

68. Little, B.W.; Perl, D.P. Oculopharyngeal muscular dystrophy. An autopsied case from the French-Canadian kindred. J. Neurol. Sci. 1982, 53, 145-158. [CrossRef]

69. Youssof, S. The relationship between physical symptoms and health-related quality of life in oculopharyngeal muscular dystrophy. Muscle Nerve 2016, 53, 694-699. [CrossRef]

70. Youssof, S.; Romero-Clark, C.; Warner, T.; Plowman, E. Dysphagia-related quality of life in oculopharyngeal muscular dystrophy: Psychometric properties of the SWAL-QOL instrument. Muscle Nerve 2017, 56, 28-35. [CrossRef] [PubMed]

71. Youssof, S.; Schrader, R.M.; Romero-Clark, C.; Roy, G.; Spafford, M. Safety of botulinum toxin for dysphagia in oculopharyngeal muscular dystrophy. Muscle Nerve 2014, 49, 601-603. [CrossRef]

72. Molgat, Y.M.; Rodrigue, D. Correction of blepharoptosis in oculopharyngeal muscular dystrophy: Review of 91 cases. Can. J. Ophthalmol. 1993, 28, 11-14. [PubMed]

73. Gliklich, R.; Dreyer, N. Registries for Evaluating Patient Outcomes: A User's Guide. In Agency for Healthcare Research and Quality; AHRQ Publication: Rockville, MD, USA, 2010; Volume 10.

74. Nakamura, H.; Kimura, E.; Mori-Yoshimura, M.; Komaki, H.; Matsuda, Y.; Goto, K.; Hayashi, Y.K.; Nishino, I.; Takeda, S.; Kawai, M. Characteristics of Japanese Duchenne and Becker muscular dystrophy patients in a novel Japanese national registry of muscular dystrophy (Remudy). Orphanet J. Rare. Dis. 2013, 8, 60. [CrossRef] [PubMed]

75. Daneshvari, S.; Youssof, S.; Kroth, P.J. The NIH Office of Rare Diseases Research patient registry Standard: A report from the University of New Mexico's Oculopharyngeal Muscular Dystrophy Patient Registry. AMIA Annu. Symp. Proc. 2013, 2013, $269-277$. [PubMed] 